\title{
Non-linear Growth Impacts of Financial Development in Euro Area
}

\author{
Maher Asal \\ Correspondence: Maher Asal, Department of Economics and IT, University West, 46186 Trollhättan, Sweden. \\ Tel: 46-52-022-3664. E-mail: maher.asal@hv.se
}

Received: July 23, 2012

doi:10.5539/ijef.v4n12p23

\author{
Accepted: August 17, $2012 \quad$ Online Published: October 23, 2012 \\ URL: http://dx.doi.org/10.5539/ijef.v4n12p23
}

\begin{abstract}
Using GMM model and data from 11 Euro Area countries and 5 non-Euro countries over the period 1989 to 2011, we explore the nonlinear effects of financial development on the performance of Euro Area economy that is: its growth, capital accumulation, investment and productivity. Four measures of financial developments are examined, namely, liquidity, size, volatility and bank's loans to private enterprises. Special consideration is devoted to modeling threshold effects of public debt that has increased substantially in recent years in several Euro countries. We found that the effect of stock market size is always positive whether we consider the level of real per capita income or its growth. However, the effect of banking sector, volatility, liquidity and public debt are generally negative. In addition, we find support for the channels of investment, saving, total factor productivity, and capital intensity. For all the four channels, the results indicate a significant negative link between banking development and volatility of stock returns. The impact of debt on growth seems to be negative with the turning point of public debt likely to be between $45-65 \%$.
\end{abstract}

Keywords: GMM, nonlinear, financial development, volatility, threshold

JEL: C23. G15. O11.

\section{Introduction}

Traditional growth theories suggest that there is no link between stock market development and economic growth. Contrary to traditional views, most recent evidences suggest that financial development is crucial in promoting economic growth (Shaw 1973; McKinnon 1973; and Goldsmith 1969). The argument is that better financial depth is associated with higher economic growth.

There are at least five channels through which EMU may improve financial development and therefore contributes to higher economic growth in Euro Area. First, to the extent the EMU affects the rate of capital accumulation; it increases profits and thus enhances economic growth. In addition, EMU decreases macroeconomic uncertainty and dampens inflation expectations, and as a result it reduces the interest rate that, in turn, surges investment and growth. This has been an important economic benefit of EMU for many of the Euro Area countries, particularly those with histories of high and volatile inflation. Furthermore, the integration of EMU financial markets has the potential to reduce the cost of capital. According to the neoclassical theory of investment a firm invests up to the point where the net present value of future cash flows equals the weighted average cost of capital (Hall and Jorgenson, 1967). Everything else being constant, a reduction in firm's cost of capital enhances productivities and thus increases investments and economic growth. Furthermore, the success of developed nations has been attributed mainly to the sustained growth of their total factor productivity (Prescott 1997).

Second, to the extent that EMU reduces volatility of Euro stock markets, it may raise the investment rate by making investment less risky (DeLong et al. 1989). The subsequent result of this higher investment is a higher long-run equilibrium capital stock and thus a higher equilibrium income per person. Third, as the variability of intra-area exchange rates was abolished, the Euro is expected to make it easier and cheaper to invest in the Euro Area resulting in extra investment that, in turn, boosts economic growth. Cheaper investment in physical assets is expected not only because of a lower cost of capital, but also because of enhanced liquidity, and a greater depth of stock markets following the introduction of the Euro. Levine (1991) show that more liquid stock markets reduce disincentives to invest in long duration projects because they can simply sell their portion in the project if they need their savings before the project matures. Increased liquidity, therefore, accelerates investment and boosts economic growth. Fourth, EMU is expected to improve the efficiency of the Euro Area economies by 
encouraging a more effective allocation of Euro Area resources (Feldman 1998; and the European Central Bank 2008. From an economy-wide perspective, the enhanced productivity implies that the same amount of capital and labor can produce more output. As the output rises, given an investment rate, induced capital formation would rise. Fifth, the Euro may drive up firm investments through changes in financial constraints that firms face. Guiso et al. (2004) argue that financial integration in Euro Area is likely to improve some firms' and countries' access to financing. An indication of improved financial development in Euro area is the large increase in corporate bond issues by firms from Euro countries (Pagano and von Thadden, 2004). In addition, the importance of public debt in determining the path of economic growth has received a great attention in the literature. Meade (1958), for example, argues that a reduction of the public debt could result in an increase of the incentive of households and possibly allow for a tax cut as a result of saving interest payments which, in turn, improves the incentives for work and enterprise. In sum, the Euro is expected to improve financial development and economic growth in the Euro Area by increasing depth and liquidity of financial markets, offering greater scope for geographical risk diversification, permitting domestic firms to access foreign financial markets (direct lending and listing on foreign stock markets), reducing volatility of Euro stock markets, increasing the efficiency of financial intermediaries, thus resulting in lower transaction costs and a more efficient allocation of capital in the Euro Area. This will enhance the overall stability and rise of nations' steady state capital stock and therefore economic growth.

The aim of this paper is to evaluate the role of finance for growth in the Euro Area. Specifically, using GMM model and data from 11 Euro Area countries and 5 non-Euro countries over the period 1989 to 2011, we explore the effects of financial development on the performance of Euro Area economy, that is: its growth, capital accumulation, investment and productivity. Four measures of financial developments are examined, namely, liquidity, size, volatility and banks' loans to private enterprises. The paper also examines the possible non-linear impact of public debt that has increased substantially in several Euro countries in recent years. Our study extends the existed literature in several ways. First, this study explores the different market behaviors between Euro and non-Euro economies. A number of economies included in this paper have not been previously examined in conjunction with each other. Second, besides examining the link between financial development indicators and real per capita GDP growth, we also investigate four channels through which stock markets and banks may be linked to growth: saving, investment, capital stock per employee, and everything else; total factor productivity. Third, we use panel data to measure the dynamic effects of development of national financial markets and real per-capita GDP growth. Such approach has been used by other authors (e.g. Edison et al. 2002; and Ben Naceur and Ghazouani 2007) that allow us to address the issue of endogeneity.

The rest of this paper is organized as follows. Section 2 highlights the link between stock market developments and economic growth. A review of the empirical findings on the link between financial developments and economic growth is also presented in the section. Section 3 presents the econometric model along with the empirical methodology. The empirical results are reported in Section 4. Section 5 concludes the paper.

\section{Literature Review}

The main view in the literature exploring the relationship between financial development and economic growth is that well-developed financial markets benefit economic agents to hedge, trade, and pool risk, thus rising investment and economic growth. Atje and Jovanovic (1993) find that stock market development stimulates economic growth in West African monetary union both in the short run and long run. However, they didn't find a similar effect for bank loans. King and Levine (1993) found a positive link between financial development indicators and economic growth, and also that the initial levels of financial development are good forecasters for production, capital and productivity growth rates for the next 30 years.

Levine and Zervos (1998) found that the initial level of liquidity and banking development are positively linked to long-term economic growth, productivity growth and capital accumulation. They also find that the size of stock markets is not a simultaneous to growth indicators. Hondroyiannis et al. (2005) study the link between the development of banking and stock markets, and economic growth in Greece over the period 1986-1999. They found that the relation between financing (stock market and bank) and overall economic activity is limited and that the effect of the stock market financing to growth is considerably smaller compared to bank financing.

That EMU will eventually lead to higher economic growth appears to be commonly supported by very little empirical evidence. Several empirical studies have tried to measure this impact (e.g., Baele et al. 2004; Hardouvelis et al. 2006; and European Central Bank 2008). A general conclusion is that Euro money markets have become fully integrated. A study by London Economics (2002) suggests that fully integrated markets could 
lower the cost of capital for EU firms by about 0.5 points, which could, in turn, raise GDP by $1.1 \%$; investment by $6 \%$; private consumption by $0.8 \%$; and employment by $0.5 \%$.

Lane (2006) argues that EMU and the resulting financial integration has contributed to more liquid and deeper financial markets in the Euro Area. The argument is that, greater financial integration stimulates economic growth, as it facilitates the ability to borrow and lend overseas, which allows individual member countries to smooth consumption in the face of temporary shocks to domestic income. It also advances the ability to diversify financial risks, reducing risk exposure of domestic wealth to domestic shocks. Van Nieuwerburgh et al. (2006) examine the long-term relationship between financial market development and economic development in Belgium and found strong evidence that the development of stock markets caused economic growth in Belgium, especially in the period between 1873 and 1914. Giannone and Reichlin (2006) argue that output levels are not converging in Europe, with the exception of the notable catch-up of Ireland's output. They suggest that cyclical asymmetries among Euro Area countries are fairly small and similar to those among US regions. Maudos and Guevara (2010) combined data at country, sector and firm level, and counted the effect of financial development on growth. They found both financial development and financial integration have been fundamental in driving the recent growth in European economies. Specifically, from 1999 to 2008, financial development has contributed 0.09 pp. of annual GDP growth in the Eurozone.

The empirical evidence on the link between debt and growth is rare and mainly concentrated on the impact of external debt in developing countries. Caner et al. (2010) analyzed the correlation between public debt and the real GDP growth in 101 developing and developed countries for the period 1980-2008. They found a threshold of $77 \%$ for the full sample and $64 \%$ for the subsample of developing countries, after which the real growth rate plunged. In these countries, the cost in yearly real growth with each extra point in public debt amounts to $0.02 \mathrm{pp}$. Rogoff and Reinhart (2010), on the other hand, found a threshold of 90 percent public debt to GDP, after which the real growth rate dropped. The threshold has useful consequence, because many Euro Area countries have reached this point while other countries expected to reach it soon and persisted above it for years. In the same vein, Checherita et al (2010) found indication for a non-linear effect of public debt on per-capita GDP growth across 12 Euro Area countries with a debt turning point at about $90-100 \%$ of GDP.

In sum, there is evidence in favor of a positive link between bank and stock market development and growth. However, the finance-growth tie is often vague across countries and over time. Therefore, a country comparison between Euro Area and non-Euro countries and between high and low debt nations enriches our knowledge of such a relationship. This is what we attempt to do next.

\section{The Empirical Methodology}

\subsection{Data}

We investigate the relationship between banking development, stock market development and real per-capita GDP growth for a sample of eleven Euro Area countries (Austria, Belgium, Finland, France, Germany, Greece, Ireland, Italy, Netherlands, Portugal, and Spain), three EU non-Euro Area economies (Denmark, Sweden, and the U.K) and the US. Data is derived primarily from the European Commission AMECO database, ECB Statistical Data Warehouse covering the period 1989-2010. To measure the link between economic growth and both stock market and banking development, we need (1) empirical measures of stock market development (2) an indicator of banking development, and (3) measures of economic activities and their channels.

Several empirical works (King and Levine 1993; Levine and Zervos 1998; and Levine 2000) have identified two measures of financial sector development that are capable to explain the differences in economic growth between countries: banking development and stock market development. In line with these studies, we use three indicators for stock market development. The first measure of stock market development is market capitalization, which reflects the size of the stock market and calculated as the value of listed domestic stocks on domestic exchanges divided by GDP. The second measure of stock market development is value traded ratio, which reflects the liquidity status of the stock market which is the value of domestic stocks traded divided by GDP. The third measure is volatility of stock market, which is a twelve-month rolling standard deviation estimate of stock market return. Economists would expect a decrease in the unconditional variance of stock returns following the introduction of the Euro as a consequence of stabilization of fundamentals and expectations. We also use the value of loans made by financial intermediaries to the private sector divided by GDP as a measure of banking development. We use two measures of economic activities: the level of real per-capita GDP and its growth, which is the log difference of real per capita GDP. Besides inspecting the link between these financial development indicators and real per capita GDP growth, we also study four channels through which banks and 
stock market developments may be linked to growth: national saving, investment, capita stock per employed (capital intensity), and everything else, productivity.

\subsection{Highpoints from the Data}

In this section we evaluate the impact of the Euro on both financial developments and real economic growth in the Euro Area. We also decompose the growth of real GDP per capita into changes of total factor productivity (TFP) and net capital stock per employed (intensity). To that end, a descriptive and analytical exploration of developments before and after the launch of the Euro is undertaken, with comparisons drawn between countries that are EMU members and non-EMU members.

Since the launch of the common currency, growth of real GDP per capita in the Euro Area has been low relative to that in the US, the UK, and Sweden. Figure 1 highlights the average yearly growth rate of real GDP per-capita in the Euro Area, the US, the UK, Sweden, Norway and Denmark. During the 1990s, growth the in the Euro Area was greater than those in the US, the UK, Sweden, and Denmark. Since the introduction of the Euro in 1999, growth in the Euro Area has lagged behind that of the US. The UK and Sweden, both of which were in the European Union since 1992, have been performing significantly better, than the other members of the EMU, whilst they have stayed outside the Euro Area.

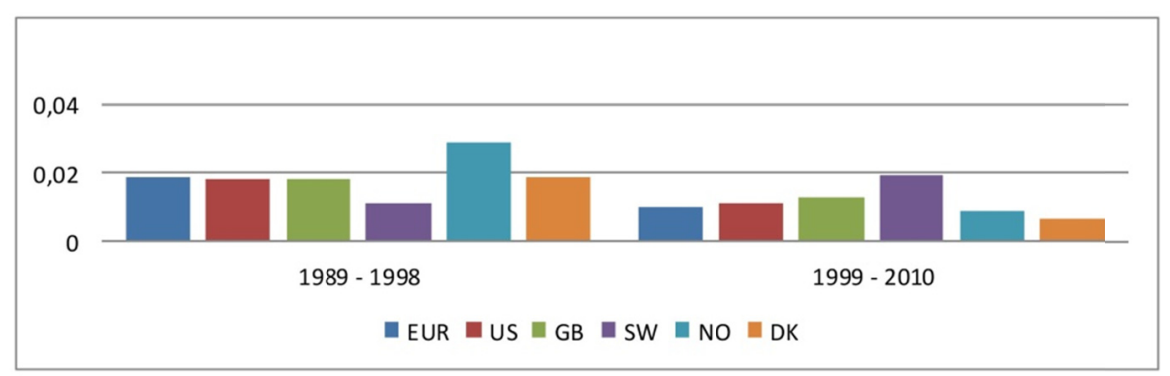

Figure 1. Growth of real GDP per capita in the Euro Area, the US, the UK, Sweden, Norway and Denmark

A decomposition of the growth of real GDP per capita into changes of total factor productivity (TFP) and net capital stock per employed (intensity) give some insight into the source of growth differentials between the Euro Area members and the other OECD countries observed in recent years. Productivity is the efficiency with which inputs are converted into output in the production process.

Levine (2000), for instance, found that the impact of financial development on growth realizes mainly through total factor productivity rather than through capital accumulation or saving rates. Figure 2 shows the changes in total factor productivity (e.g. Solow residual) which represents output growth not accounted for by the growth in the inputs (Hornstein and Krusell, 1996). From 1989 to 1998, total factor productivity in the Euro Area grew at a lower rate compared to all other countries under examination. However, total factor productivity grew noticeably more slowly in the Euro Area in the post Euro era, and is largely responsible for the weakening growth of real GDP per capita recorded.

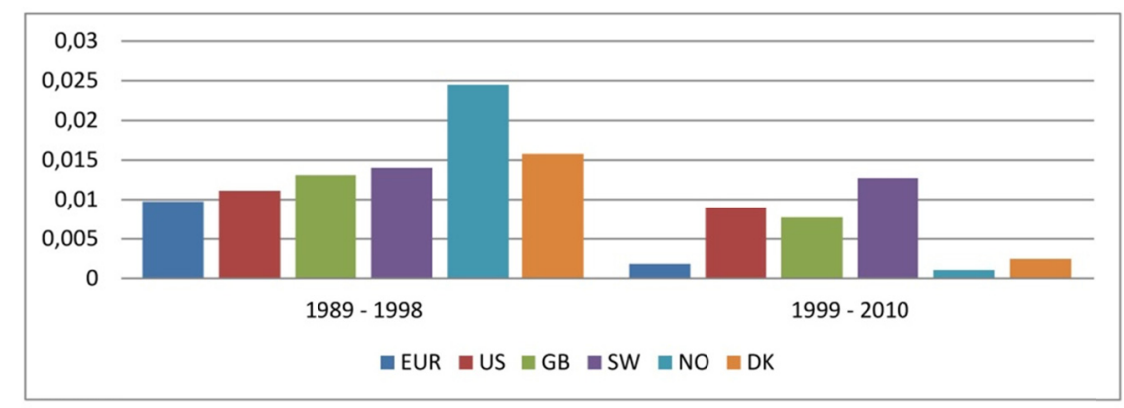

Figure 2. Average changes of Total Factor Productivity in the Euro Area, the US, the UK Sweden, Norway and Denmark 
Figure 3 shows the changes in the net capital stock per employed (capital intensity) in the Euro Area compared to the US, the UK, Sweden, Norway and Denmark. From 1989 to 1998, capital intensity in the Euro Area grew at a faster rate than those in the US, the UK, Norway and Denmark. However, capital intensity grew much more slowly in the Euro Area over the post Euro era, and is also to blame for the noted weaker output growth.

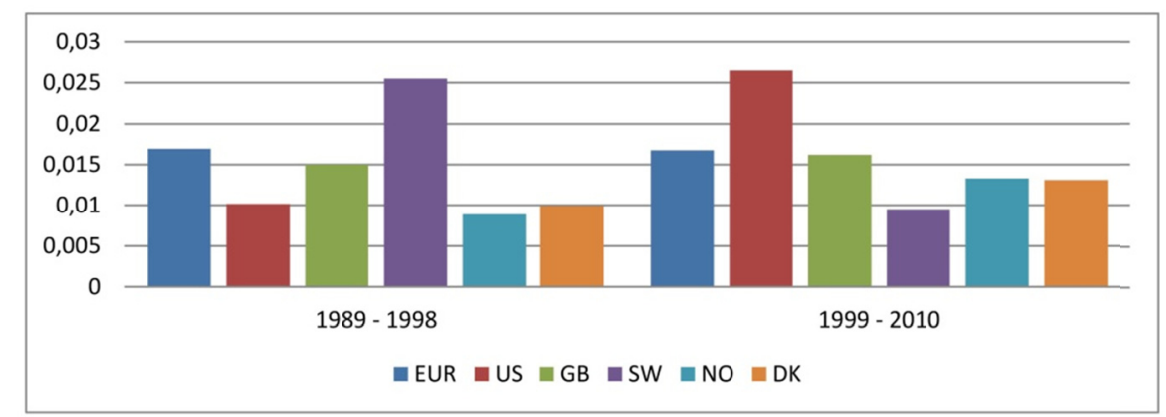

Figure 3. Changes in net capital stock per employed (capital intensity) in the Euro Area, the US, the UK, Sweden, Norway and Denmark

A closer look at the real GDP growth, total factor productivity and capital intensity in individual Euro Area members reveal a significant degree of variation in rates across the 11 member states. The growth rates of real GDP per-capita shown in table 1 suggest that the weak performance in the post Euro era was driven primarily by slow growth in France, Italy and Portugal, each of which expanded at an average rate of less than 0,1 per cent per annum over the 12-year period from 1999 to 2010. Similarly, the growth rates of total factor productivity shown in table 1 suggest that the fragile performance in the post Euro era was driven mainly by negative growth in Spain and Italy as well as a slow growth in France over the same period from 1999 to 2010. Finally, the growth rates of capital intensity shown in table 1 indicates that the weak performance in the post Euro era was run mainly by slow growth in Germany, Belgium and Finland each of which expanded at a yearly average rate of less than $0,1 \%$ over the 12-year period from 1999 to 2010.

Table 1. Growth of real GDP per capita, total factor productivity and capital intensity in Euro Area- country detail

\begin{tabular}{lllllll}
\hline & \multicolumn{2}{c}{ Real GDP per capita } & \multicolumn{3}{c}{ Total Factor Productivity } & \multicolumn{2}{c}{ Capital Intensity } \\
\cline { 2 - 7 } & $1989-1998$ & $1999-2010$ & $1989-1998$ & $1999-2010$ & $1989-1998$ & $1999-2010$ \\
\hline AT & 0,022 & 0,015 & 0,014 & 0,007 & 0,028 & 0,014 \\
BL & 0,018 & 0,012 & 0,008 & 0,004 & 0,019 & 0,008 \\
FI & 0,013 & 0,020 & 0,020 & 0,011 & 0,023 & 0,008 \\
FR & 0,015 & 0,009 & 0,009 & 0,001 & 0,019 & 0,014 \\
DE & 0,018 & 0,012 & 0,010 & 0,004 & 0,003 & 0,007 \\
GR & 0,011 & 0,020 & 0,007 & 0,009 & 0,013 & 0,018 \\
IR & 0,058 & 0,022 & 0,035 & 0,004 & 0,001 & 0,039 \\
IT & 0,016 & 0,001 & 0,010 & $-0,001$ & 0,021 & 0,013 \\
NL & 0,025 & 0,014 & 0,012 & 0,007 & 0,004 & 0,014 \\
PT & 0,030 & 0,008 & 0,017 & 0,002 & 0,033 & 0,025 \\
SP & 0,024 & 0,013 & 0,003 & $-0,001$ & 0,023 & 0,023 \\
\hline
\end{tabular}

Notice that the Euro Area consists of the eleven Euro countries, AT= Austria, BL $=$ Belgium, FI $=$ Finland, $\mathrm{FR}=$ France, $\mathrm{DE}=$ Germany, $\mathrm{GR}=$ Greece, $\mathrm{IR}=$ Ireland, $\mathrm{IT}=$ Italy, $\mathrm{NL}=$ Netherlands, $\mathrm{PT}=$ Portugal, $\mathrm{SP}=\mathrm{Spain}, \mathrm{GB}$ $=$ Great Britain, $\mathrm{SW}=$ Sweden, $\mathrm{NO}=$ Norway, $\mathrm{DK}=$ Denmark and US $=$ United States

Figure 4 highlights the average annual changes of bank credit to private sector as percentage of GDP in the Euro Area as well as for non-Euro countries. From 1989 to 1998, although loans made by banks to private enterprises as percentage of GDP in the Euro Area grew at a lower rate than in the US, it grew faster than those in the UK, 
Norway, Sweden and Denmark. However, loans made by banks to private enterprises grew remarkably faster in the Euro Area than in the US, Sweden and Norway in the post Euro era.

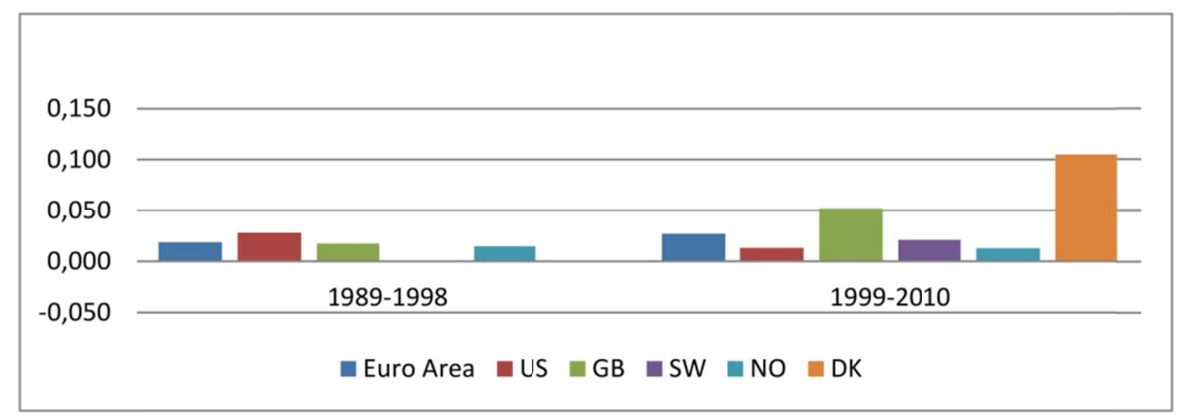

Figure 4. Changes in bank credit to the private sector as a percentage of GDP

Figure 5 highlights the average annual changes in market capitalization as a percentage of GDP in the Euro Area as well in the non-Euro countries. In the US and the Euro Area growth was similar during the 1990s whilst Swedish, UK, Norwegian and Danish growth rates were generally lower than those in the US and the Euro Area over the same period. Since 1999 growth of market capitalization in the Euro Area, the US and the UK turned negative and lagged behind that of other economies.

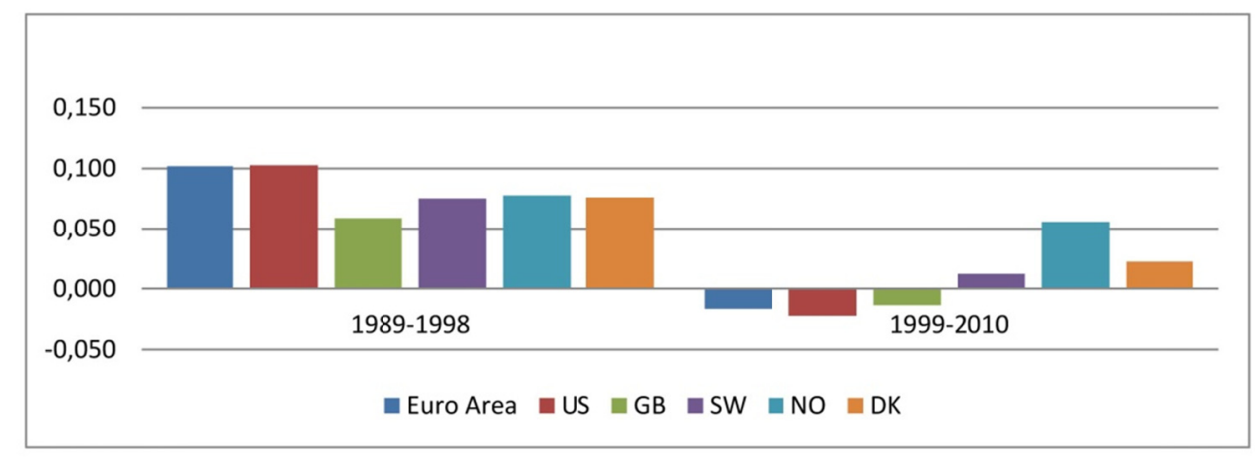

Figure 5. Changes in market capitalization as a percentage of GDP

Figure 6 shows changes in liquidity for the same countries. In the Euro Area growth was higher than that of the UK during the 1990s whilst US, Swedish, Norwegian and Danish growth rates were generally much higher than those in the US and the Euro Area over the same period. Since 1999 growth of liquidity in the Euro Area, the US and the UK turned negative and lagged behind that of other economies.

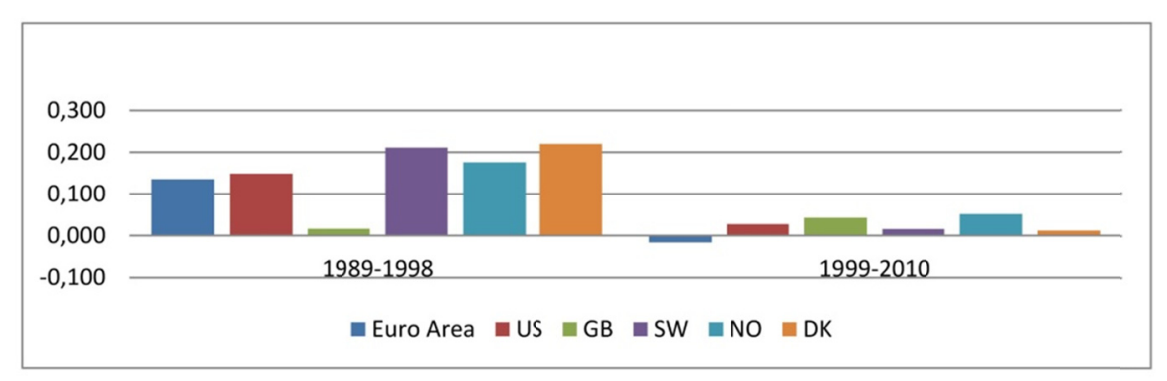

Figure 6. Changes in liquidity, measured by the value of domestic shares traded \% of GDP

Figure 7 displays volatility of stock returns in the Euro Area, the US, the UK, Sweden, Norway and Denmark. Volatility in the Euro Area was higher than that of the US and UK during the 1990s whilst volatility in Sweden, Norway and Denmark were generally much higher than any of the other countries in our sample. Since 1999 
volatility has increased dramatically in all countries, apart from Sweden and Norway where volatility fell remarkably. Thus, besides slower growth of total factor productivity in Euro Area since 1999, the increase in stock market volatility as well as negative growth of market capitalization and liquidity are considered additional factors behind slower growth of real-capita GDP in Euro Area.

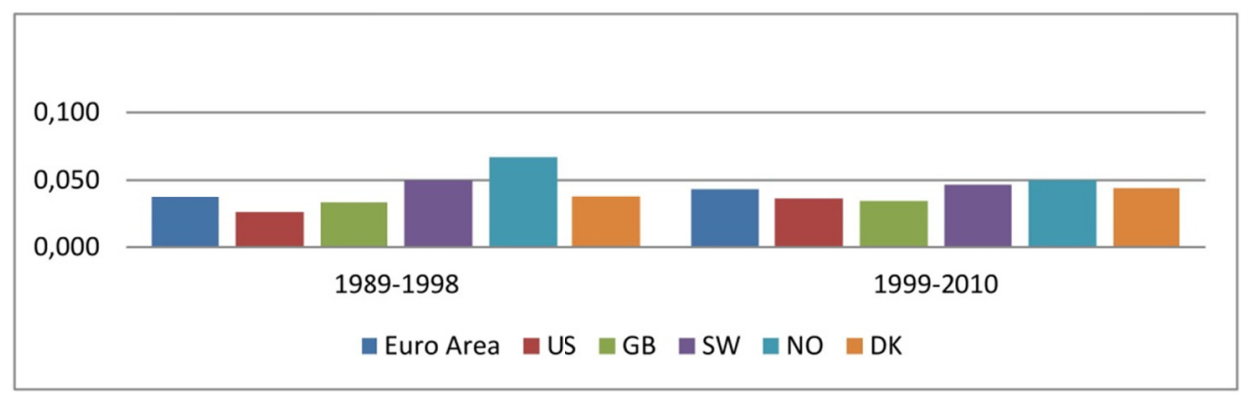

Figure 7. Volatility of stock returns in the Euro Area, the US, the UK, Sweden, Norway and Denmark

A closer inspection of the banking and stock market development in individual Euro Area members reveals a substantial degree of variation in rates across the 11 member states. Table 2 presents descriptive statistics of the individual banking and stock market development in the Euro Area over the period 1989-2010. We highlight four points. First, the fast growing loans made by banks to private enterprises (e.g. banking development) in the Euro Area in the post Euro period was driven primarily by fast growing loans in Spain, Portugal, Ireland and Finland. Second, the weak growth of market capitalization in the Euro Area in the post Euro era was driven mainly by weak growth in Italy, Ireland, Greece, and the Netherlands. Third, the weak growth of liquidity in the Euro Area in the post Euro era was driven mainly by weak growth in Ireland, Portugal and Italy. Fourth, the remarkable increase in volatility in the Euro Area over the same period was driven mainly by notable increase in volatility in Finland, Ireland, Netherlands and Germany.

Table 2. Descriptive statistics of bank development and stock market development in the Euro Area- country details (average annual changes)

\begin{tabular}{lllllllll}
\hline & \multicolumn{7}{c}{ Bank Development } & \multicolumn{7}{c}{ Stock Market Development } \\
\cline { 2 - 9 } & $\mathbf{1 9 8 9 - 1 9 9 8}$ & $\mathbf{1 9 9 9 - 2 0 1 0}$ & \multicolumn{3}{c}{$\mathbf{1 9 8 9 - 1 9 9 8}$} & \multicolumn{3}{c}{$\mathbf{1 9 9 9 - 2 0 1 0}$} \\
\cline { 2 - 10 } & Bank & Bank & CAP & VT & VOL & CAP & VT & VOL \\
\hline AT & 0,044 & 0,045 & 0,035 & 0,094 & 0,06 & 0,046 & 0,065 & 0,056 \\
BL & 0,072 & $-0,015$ & 0,096 & 0,142 & 0,035 & $-0,05$ & 0,02 & 0,04 \\
FI & $-0,03$ & 0,052 & 0,144 & 0,195 & 0,061 & $-0,103$ & $-0,018$ & 0,068 \\
FR & 0,007 & 0,02 & 0,101 & 0,182 & 0,043 & 0,01 & 0,023 & 0,043 \\
DE & 0,039 & $-0,007$ & 0,099 & 0,03 & 0,038 & $-0,023$ & 0,009 & 0,048 \\
GR & $-0,016$ & 0,037 & 0,231 & 0,438 & 0,089 & $-0,114$ & $-0,07$ & 0,06 \\
IR & 0,053 & 0,081 & 0,225 & 0,304 & 0,05 & $-0,127$ & $-0,147$ & 0,05 \\
IT & 0,007 & 0,041 & 0,109 & 0,236 & 0,056 & $-0,103$ & $-0,053$ & 0,045 \\
NL & 0,022 & 0,049 & 0,116 & 0,199 & 0,033 & $-0,071$ & $-0,029$ & 0,047 \\
PT & 0,023 & 0,066 & 0,138 & 0,294 & 0,046 & $-0,018$ & $-0,062$ & 0,044 \\
SP & 0,001 & 0,07 & 0,099 & 0,281 & 0,048 & 0,025 & $-0,006$ & 0,044 \\
\hline
\end{tabular}

\subsection{Econometric Modeling}

We investigate the link between financial development and per-capita GDP in a sample of 16 countries (Euro Area 11, and 5 non-Euro countries) described above. Using such cross-sectional samples helps to highlight the problem of heterogeneity. The model is enlarged to include the level of public debt as a share of GDP. Other control variables such as inflation rate, long term interest rate and openness indicator (which is the sum of export and import as a share of GDP) are also included to capture the overall macroeconomic instability. Having in mind all criteria mentioned above, we estimate the following baseline empirical model (Note 1) 


$$
y_{i t}=\sum_{k=1}^{p} \alpha_{k} y_{i, t-k} \quad \beta_{1} S_{i t}+\beta_{2} B_{i t}+\beta_{3} W_{i t}+\beta_{\mathbf{4}} X_{i t}+\lambda_{t}+\eta_{i}+v_{i t}
$$

The dependent variable, $y_{i t}$, is the real per-capita GDP in country (i) for time $(t)$. $S_{i t}$, is a vector of financial development indicators (e.g. size, liquidity and volatility), $\mathrm{B}_{\mathrm{it}}$, is the proxy of bank development (measured by the domestic credit provided by the banking sector as a share of GDP), $\mathrm{W}_{\mathrm{it}}$ is a set of control variables (including openness, inflation, school enrollment, R \& D as percentage of GDP and long term interest rate). $X_{\mathrm{it}}$ is the public debt as a percentage of GDP, $\eta_{\mathrm{i}}$ and $\lambda_{\mathrm{t}}$ are individual and time specific effects, respectively. The latter allows us to control for time-invariant determinants of growth such as human capital. The lagged real GDP per capita, $\mathrm{y}_{\mathrm{i}, \mathrm{t}-\mathrm{k}}$, is also included to capture aggregate business cycle fluctuations as in accelerator models of investment. The $\mathbf{v}_{\mathbf{i t}}$ are presumed to be independently distributed with zero mean and is not serially correlated with the explanatory variables $\mathrm{S}_{\mathrm{it}}, \mathrm{B}_{\mathrm{it}}, \mathrm{W}_{\mathrm{it}}$, and $\mathrm{X}_{\mathrm{it}}$. We use the lag of the explanatory variables to circumvent the endogeneity problem posed by this variable.

We estimate the baseline equations 1 using dynamic panel GMM procedure with fixed effect to control for the endogeneity bias (reverse causality) running from GDP to financial development and other explanatory variables. The fixed effect model is designated to capture cross-country difference in economic conditions, such as saving rate, population growth rate (Solow 1956), and the degree of openness to cross-border trade, which determines the steady-state growth path of per-capita GDP. In addition, given the high possibility potential for endogeneity of financial development, we use various instrumental variable estimation techniques. Most studies on growth regressions in a panel framework (e.g. Hiebert et al. 2002) have used the instrumental variable (IV) method to deal with the simultaneity bias. With the GMM, we also correct for the heteroscedasticity and autocorrelation that may appear in the error term.

\section{Empirical Results}

Various dynamic specifications of the panel model were estimated using equation (1). Our sample of 16 countries is decomposed into three groups; all countries; 11 Euro Area countries; and 5 non-Euro countries. Table 3 reports GMM- estimates of two regressions of the base equation (1), where the dependent variables are the level of GDP per capita (column 2-4) and the growth of real GDP per capita (column 6-8) over the period ranging from 1989 to 2010. All estimated equations seem to be statistically well specified. Choice of dynamic specification is supported by highly significant coefficients on lagged GDP per capita. In addition to other standard statistics at the bottom of the table, two Wald tests (to test for the joint significance of all coefficients and time dummies, respectively) and two AR tests (to test the null of no serial correlation of first- and second-order,) are reported. Moreover, Sargan tests for over identifying restrictions confirmed the validity of the instrument sets used in GMM estimation.

The results shown in column (2)-(4) reveal some important facts related the determination of real per capita income. Firstly, the impact of stock market size is always positive and highly significant at $1 \%$ significance level across the three groups. Second, the effect of banking sector is continuously negative and significant at $1 \%$ significance level in two groups: the whole sample and non-Euro countries. The negative relationship between bank development and per capita real GDP may be directly linked to the overwhelming public sector in the credit allocation. Unexpectedly, the impact of liquidity is also negative at $1 \%$ significance level in all groups. Volatility of stock market return, as expected, is negatively related to per capita real GDP at $5 \%$ significance level in all cases. So, apart from stock market size, the financial sector has no encouraging impact on real GDP per capita regardless of whether we take stock market development or banking development measures. Thirdly, the impact of public debt is highly negative at $1 \%$ significance level in all cases. Finally, the other explanatory variables generally enter the regressions as expected. Inflation rate and long term interest rate as control variables for overall macroeconomic instability are significantly negative at different significance level in all cases.

As robustness check, column (6)-(8) in table 3 estimates the same equation where the dependent variable is growth of real GDP per capita. As shown, the size of the stock markets positively affects growth of GDP per capita at $1 \%$ significance in all cases. The effect of the banking sector, however, turns out to be negative and highly insignificant in most cases. The impact of liquidity on growth is insignificantly positive for Euro Area and for the non-Euro countries, but is significant at only $10 \%$ level for all countries. The impact of public debt is negative at $1 \%$ significance level in two groups; all countries and the Euro Area, but insignificant for the non-Euro countries. The effect of inflation rate and volatility on growth turns out to be negligible and highly 
insignificant in all cases. Finally, the effect of long-term interest rates is negative at $10 \%$ significance level for the Euro Area, but insignificant in the other two groups.

In sum, the impact of stock market size is always positive and highly significant at $1 \%$ significance level across the three groups whether we take the level of real per capita income or its growth. The impact of banking sector turned out to be negative and significant in most cases whether we take the level of real per capita income or its growth. The impact of liquidity is either negative or insignificant in most cases. The volatility of stock market return is either negative or insignificant in all cases. The impact of public debt is highly negative in most cases. The impact of long-term interest rates is negative predominantly in the Euro Area. Finally, the impact of inflation rate is either negative or insignificant in most cases.

Table 3. One step GMM- estimates of the relationship between stock markets, banks and growth in Euro Area, the US, the UK, Sweden, Norway and Denmark; one-step

\begin{tabular}{|c|c|c|c|c|c|c|c|}
\hline & & & Level & & & & Growth \\
\hline & All Countries & Euro Countries & NON-EURO & & All Countries & Euro Countries & NON-EURO \\
\hline \multirow[t]{2}{*}{$\mathrm{y}_{\mathrm{t}-1}$} & $1,128 * * *$ & $0,982 * * *$ & $1,039^{* * *}$ & $\Delta \mathrm{y}_{\mathrm{t}-1}$ & $0,122 *$ & $0,175^{* * *}$ & $0,064^{*}$ \\
\hline & $(0,092)$ & $(0,007)$ & $(0,018)$ & & $(0,067)$ & $(0,050)$ & $(0,112)$ \\
\hline \multirow[t]{2}{*}{ Bank } & $-0,019 * * *$ & $-0,011$ & $-0,026^{* * *}$ & $\Delta$ Bank & $-0,005$ & 0,011 & $-0,003$ \\
\hline & $(0,005)$ & $(0,025)$ & $(0,004)$ & & $(0,005)$ & $(0,018)$ & 0,005 \\
\hline \multirow[t]{2}{*}{ CAP } & $0,006 * * *$ & $-0,003$ & 0,012 & $\triangle \mathrm{CAP}$ & $0,006^{*}$ & 0,002 & $0,005 *$ \\
\hline & $(0,004)$ & $(0,005)$ & $(0,007)$ & & $(0,003)$ & $(0,004)$ & $(0,003)$ \\
\hline \multirow[t]{2}{*}{$\mathrm{CAP}_{\mathrm{t}-1}$} & 0,015 & $0,021 * * *$ & $0,021 * * *$ & $\Delta \mathrm{CAP}_{\mathrm{t}-1}$ & $0,036^{* * *}$ & $0,03^{* * *}$ & $0,03 * * *$ \\
\hline & $(0,004)$ & $(0,004)$ & $(0,005)$ & & $(0,004)$ & $(0,003)$ & $(0,008)$ \\
\hline \multirow{2}{*}{$\mathrm{VT}_{\mathrm{t}-1}$} & $-0,013 * * *$ & $-0,015^{* * *}$ & $-0,011^{* * *}$ & $\Delta \mathrm{VT}$ & $0,005^{*}$ & 0,004 & 0,003 \\
\hline & $(0,003)$ & $(0,002)$ & $(0,007)$ & & $(0,003)$ & $(0,003)$ & $(0,003)$ \\
\hline \multirow[t]{2}{*}{ Vol } & $-0,145^{* *}$ & $-0,076$ & $-0,046$ & Vol & $-0,098 * *$ & $-0,069$ & 0,021 \\
\hline & $(0,061)$ & $(0,072)$ & $(0,124)$ & & $(0,043)$ & $(0,063)$ & $(0,096)$ \\
\hline \multirow[t]{2}{*}{$\mathrm{Vol}_{\mathrm{t}-1}$} & $-0,136^{* *}$ & $-0,079 * *$ & $-0,284 * *$ & $\mathrm{Vol}_{\mathrm{t}-1}$ & 0,034 & 0,079 & $-0,016$ \\
\hline & $(0,058)$ & $(0,035)$ & $(0,093)$ & & $(0,058)$ & $(0,081)$ & $(-0,028)$ \\
\hline \multirow[t]{2}{*}{$\mathrm{Dbt}$} & $-0,093 * * *$ & $-0,15^{* * *}$ & $-0,049 * * *$ & $\Delta \mathrm{Dbt}$ & $-0,08 * * *$ & $-0,093^{* * *}$ & $-0,046$ \\
\hline & $(0,018)$ & $(0,021)$ & $(0,004)$ & & $(0,017)$ & $(0,012)$ & $(-0,024)$ \\
\hline \multirow[t]{2}{*}{$\mathrm{Db}_{\mathrm{t}-1}$} & $0,085^{* * *}$ & $0,14 * * *$ & $0,052 * * *$ & $\Delta \mathrm{Dbt}_{\mathrm{t}-1}$ & $-0,058 * * *$ & $-0,071 * * *$ & 0,004 \\
\hline & $(0,018)$ & $(0,021)$ & $(0,005)$ & & $(0,016)$ & $(0,014)$ & $(0,014)$ \\
\hline \multirow[t]{2}{*}{$\operatorname{Inf}_{t-1}$} & $-0,001 *$ & $-0,001$ & $-0,002 * *$ & Inf & 0,001 & 0,002 & 0,003 \\
\hline & $(0,001)$ & $(0,001)$ & $(0,001)$ & & $(0,231)$ & $(0,001)$ & $(0,145)$ \\
\hline \multirow[t]{2}{*}{$\mathrm{Li}_{\mathrm{t}-1}$} & $-0,004 * *$ & $-0,004^{*}$ & $-0,003 *$ & $\mathrm{Li}_{\mathrm{t}-1}$ & $-0,002$ & $-0,002 *$ & $-0,003$ \\
\hline & $(0,001)$ & $(0,002)$ & $(0,001)$ & & $(0,001)$ & $(0,002)$ & $(0,001)$ \\
\hline \multirow[t]{2}{*}{ Const. } & $0,222 * *$ & $0,248 * * *$ & $-0,301$ & Const. & 0,013 & 0.007 & 0,004 \\
\hline & $(0,073)$ & $(0,071)$ & $(0,222)$ & & $(0,005)$ & $(0.003)$ & $(0,009)$ \\
\hline Wald $_{\text {joint: }} \times 2(16)$ & $2.3 \mathrm{e}[0.000]^{* *}$ & $6.642 \mathrm{e}[0.000] * *$ & $\begin{array}{l}4.860 \\
{[0.000] * *}\end{array}$ & & $\begin{array}{l}1.393 \\
{[0.000] * *}\end{array}$ & $1.661[0.000] * *$ & $\begin{array}{l}12.24 \\
{[0.661]}\end{array}$ \\
\hline & $9.189[0.002]$ & 12.19 & $1832[0176$ & & 7.747 & $4037[0.045] *$ & 0.2108 \\
\hline Wald dummy $_{\text {di) }} \chi 2(1)$ & $* *$ & {$[0.000] * *$} & $1.832[0.1 / 6$ & & {$[0.005] * *$} & $4.03 /[0.045]^{*}$ & {$[0.646$} \\
\hline Sargan test: $\chi_{(215)}^{2}$ & $202.3[0.723]$ & $\begin{array}{l}169.8 \\
{[0.991]}\end{array}$ & $71.60[1.000]$ & & $162.5[0.997]$ & $140.6[1.000]$ & $\begin{array}{l}56.72 \\
{[1.000]}\end{array}$ \\
\hline $\operatorname{AR}(1)$ test: $\mathrm{N}(0,1)$ & $2.317[0.020] *$ & $\begin{array}{l}1.955 \\
{[0.051]}\end{array}$ & $1.663[0.096]$ & & $\begin{array}{l}2.203[0.028] \\
*\end{array}$ & $0.7618[0.446]$ & $\begin{array}{l}1.306 \\
{[0.191]}\end{array}$ \\
\hline $\operatorname{AR}(2)$ test: $\mathrm{N}(0,1)$ & $3.428[0.001] * *$ & $\begin{array}{l}2.016 \\
{[0.044] *}\end{array}$ & $-1.686[0.092]$ & & $1.922[0.055]$ & $1.339[0.181]$ & $\begin{array}{l}1.209 \\
{[0.227]}\end{array}$ \\
\hline
\end{tabular}

Notes: First step GMM results. Standard errors are in parenthesis. ${ }^{* * *},{ }^{* *},{ }^{*}$ denote significance at $1,5,10 \%$, respectively. We use the lags of all variables as instruments in the GMM estimation. Sargan test is the test for overidentifying restrictions. $\mathrm{y}_{(-1)}=\log$ of one lag real per-capita GDP; Bank = log of loans made by banks to private enterprises as a percentage of GDP, CAP $=\log$ of market capitalization as percentage of GDP, $\mathrm{VOL}=$ volatility of stock market returns, $\mathrm{Li}=$ long term interest rate, inf. $=$ inflation rate, $\mathrm{VT}=\log$ of the value of stock trading as percentage of GDP, DBT $=\log$ of government debt as percentage of GDP, and Const. $=$ constant, $\Delta$ indicates the first difference of the variable and subscription ( $\mathrm{t}-1)$ indicates lagged values. 
The results shown in column (6-8) reveal an important difference between the determination of real per capita GDP growth in the Euro Area and the non-Euro counties. While the negative effect of public debt and long term interest rate on growth occurs merely in the Euro Area, the positive impact of market capitalization arises solely in the non-Euro countries.

\subsection{Channels for the Effect of Financial Development on Economic Growth}

Besides examining the link between financial development and real per capita GDP growth, we also examine the impact of bank and stock market development on: (i) national savings (\% of GDP); (ii) investment (measured by gross fixed capital formation \% of GDP); (iii) total factor productivity; and (iv) net- capita stock per employed (capital intensity). As before, we use dynamic panel estimation since shocks to private saving rate is likely to be highly persistent. Besides using the lagged private saving and the public debt variables, we also include other control variables as the foremost determinants of saving (see for instance Levine and Zeros 1998; Masson et al. 1998; and Checherita and Rother 2010). Therefore, the level of the private saving is presumed to be determined by: (i) the level of GDP per-capita $\left(\mathrm{y}_{\mathrm{it}}\right)$; (ii) stock market development $\left(\mathrm{S}_{\mathrm{it}}\right)$, proxied by market capitalization, liquidity and volatility; (iii) bank development, proxied by the domestic credit provided by banking sector (\% of GDP); (vi) other control variables $\left(\mathrm{W}_{\text {it }}\right)$ such as openness and long term interest rate. Thus we use the following regression in analyzing the channel of private saving ratio:

$$
\text { Saving }_{i t}=\sum_{k=1}^{p} \alpha_{k} \text { Saving }_{i, t-k}+y_{i t}, \beta_{1} S_{i t}+\beta_{2} B_{i t}+\beta_{3} W_{i t}+\beta_{4} X_{i t}+\lambda_{t}+\eta_{i}+v_{i t}
$$

Table 4 reports GMM- estimates for the saving ratios along with Wald test for testing the significance of explanatory variables, Sargan test for testing for the validity of instrumental variables, and AR test for testing for autocorrelation. As shown in table 4, all estimated equations seem statistically well specified. We find that the impact of stock market size is positive in most cases but insignificant. The impacts of banking sector and volatility are negative on saving ratio in all cases at different significance levels. The impact of liquidity is negative but highly insignificant in all cases. Apart from the non-Euro countries, the impacts on long term interest rate and public debt are negative but insignificant. Finally, inflation rates turned out to be negligible in determining saving rates in all cases. In sum, financial sector doesn't have any positive impact on saving whether we consider stock market development or banking development measures.

Table 4. Analysis of Channels through which bank and financial development may influence economic growth. 1- National Saving (\% of GDP)

\begin{tabular}{|c|c|c|c|c|c|c|}
\hline \multirow[b]{2}{*}{ Variable } & \multicolumn{2}{|c|}{ All Countries } & \multicolumn{2}{|c|}{ Euro Area } & \multicolumn{2}{|c|}{ Non-Euro } \\
\hline & Coefficient & std.error & Coefficient & std.error & Coefficient & std.error \\
\hline $\mathrm{S} / \mathrm{Y}_{\mathrm{t}-1}$ & $0,880 * * *$ & 0,045 & $0,851^{* *}$ & 0,076 & $0,785437 * * *$ & 0,03 \\
\hline $\mathrm{RCP}_{\mathrm{t}-1}$ & $-0,013$ & 0,017 & $-0,042 *$ & 0,022 & $-0,026$ & 0,02 \\
\hline Bank $_{t-1}$ & $-0,069 * * *$ & 0,01 & $-0,059 * * *$ & 0,017 & $-0,044 * *$ & 0,014 \\
\hline $\mathrm{CAP}_{\mathrm{t}-1}$ & 0,022 & 0,019 & 0,028 & 0,018 & $-0,028$ & 0,029 \\
\hline $\mathrm{VT}_{\mathrm{t}-1}$ & $-0,016$ & 0,016 & $-0,012$ & 0,014 & $-0,006$ & 0,019 \\
\hline $\mathrm{Vol}_{\mathrm{t}-1}$ & $-0,660 * * *$ & 0,112 & $-0,578 * * *$ & 0,128 & $-0,730 *$ & 0,4 \\
\hline $\mathrm{Dbt}_{\mathrm{t}-1}$ & 0,019 & 0,017 & $-0,004$ & 0,015 & $0,070 * * *$ & 0,017 \\
\hline $\operatorname{Inf}_{t-1}$ & $-0,002$ & 0,002 & $-0,004$ & 0,002 & 0 & 0,002 \\
\hline $\mathrm{Li}_{\mathrm{t}-1}$ & $-0,006$ & 0,004 & $-0,003$ & 0,004 & $-0,013 * * *$ & 0,002 \\
\hline Const. & $0,781 * *$ & 0,327 & $1,145^{* *}$ & 0,451 & $1,084 * * *$ & 0,275 \\
\hline Wald $_{\text {joint }}: \chi 2(9)$ & \multicolumn{2}{|c|}{ 4557. [0.000] ** } & \multicolumn{2}{|c|}{$1.506[0.000]^{* *}$} & \multicolumn{2}{|l|}{$1081 .[0.000]^{* *}$} \\
\hline Wald $_{\text {dummy }} \chi 2(1)$ & \multicolumn{2}{|c|}{$5.695[0.017] *$} & \multicolumn{2}{|c|}{$6.442[0.011]^{*}$} & \multicolumn{2}{|l|}{$15.54[0.000]^{* *}$} \\
\hline Sargan test: $\chi^{2}(222)$ & \multicolumn{2}{|c|}{$211.8[0.677]$} & \multicolumn{2}{|c|}{$1.871[0.061]$} & \multicolumn{2}{|l|}{$70.64[1.000]$} \\
\hline $\mathrm{AR}(1)$ test: $\mathrm{N}(0,1)$ & \multicolumn{2}{|c|}{$2.656[0.008] * *$} & \multicolumn{2}{|c|}{$-0.9095[0.363]$} & \multicolumn{2}{|l|}{$1.975[0.048]^{*}-$} \\
\hline $\operatorname{AR}(2)$ test: $\mathrm{N}(0,1)$ & \multicolumn{2}{|c|}{$-0.9372[0.349]$} & \multicolumn{2}{|c|}{$-0.9372[0.349]$} & \multicolumn{2}{|l|}{$-0.9372[0.349]$} \\
\hline
\end{tabular}

We use the one lag of all variables as instruments in the GMM estimation. Sargan test is the test for overidentifying restrictions. $\mathrm{S} / \mathrm{Y}_{\mathrm{t}-1}=\log$ of lagged saving as percentage of GDP. For the abbreviations of the other variables see notes below table 3 .

Turning to the path of private investment, the estimation equation for gross fixed capital formation is as follows: 


$$
I n v_{\cdot i t}=\sum_{k=1}^{p} \alpha_{k} I n v_{\cdot i, t-k}+y_{i t}, \beta_{1} S_{i t}+\beta_{2} B_{i t}+\beta_{3} W_{i t}+\beta_{4} X_{i t}+\lambda_{t}+\eta_{i}+v_{i t}
$$

Table 5 reports GMM estimates for the investment ratio using equation (3) where all estimated equations appear to be well identified. First, the impact of real per capita GDP on investment is unexpectedly negative but insignificant in most cases. Secondly, the impacts of the banking sector and volatility are negative at $1 \%$ significance level in all cases. Thirdly, the impact of the size of the stock market is significant and positive in most cases. While the impact of public debt on investment is negative in the Euro Area at $10 \%$ significance level, it is positive in the non-Euro Area countries. In addition, as expected, the impacts of inflation rate and long term interest rate on investment are negative but insignificant in most cases. Finally, the impact of liquidity turned out to be negligible in determining investment ratio.

Switching to the channel of total factor productivity (TFP), similar to Pattillo et al. (2002) and Checherita et al. (2010), we also investigate the effect of financial development on total factor productivity (TFP), using the following regression:

$$
T F P_{i t}=\sum_{k=1}^{p} \alpha_{k} T F P_{i, t-k}+y_{i t}, \beta_{\mathbf{1}} S_{i t}+\beta_{2}, B_{i t}+\beta_{3} W_{i t}+\beta_{4} X_{i t}+\lambda_{t}+\eta_{i}
$$

Table 5. Analysis of Channels through which bank and financial development may influence economic growth. 2-

\begin{tabular}{|c|c|c|c|c|c|c|}
\hline & \multicolumn{2}{|c|}{ All Countries } & \multicolumn{2}{|l|}{ Euro Area } & \multicolumn{2}{|l|}{ Non-Euro } \\
\hline & Coefficient & std. error & Coefficient & std.error & Coefficient & std.error \\
\hline $\mathbf{I} / \mathbf{Y}_{\mathrm{t}-1}$ & $1,052 * * *$ & 0,014 & $1,041 * * *$ & 0,021 & $1,004 * * *$ & 0,021 \\
\hline $\mathbf{R C P} \mathbf{P}_{t-1}$ & $-0,013$ & 0,012 & $-0,036^{*}$ & 0,018 & $-0,024$ & 0,048 \\
\hline Bank $_{t-1}$ & $-0,075 * * *$ & 0,01 & $-0,053 * * *$ & 0,016 & $-0,091 * * *$ & 0,011 \\
\hline CAP $_{t-1}$ & $0,027 * * *$ & 0,008 & $0,013 *$ & 0,006 & $-0,014$ & 0,025 \\
\hline$V T_{t-1}$ & 0 & 0,004 & 0,006 & 0,005 & 0,001 & 0,019 \\
\hline Vol $t_{t-1}$ & $-1,356 * * *$ & 0,136 & $-0,933 * * *$ & 0,158 & $-1,744 * * *$ & 0,332 \\
\hline Dbt $_{t-1}$ & 0,017 & 0,011 & $-0,120^{*}$ & 0,064 & $0,043^{*}$ & 0,024 \\
\hline $\operatorname{Inf}_{t-1}$ & $-0,002 *$ & 0,001 & $-0,004$ & 0,002 & $-0,001$ & 0,002 \\
\hline $\mathbf{L} \mathbf{i}_{\mathrm{t}-1}$ & 0,002 & 0,002 & 0,002 & 0,003 & $-0,006^{*}$ & 0,003 \\
\hline Const. & 0,192 & 0,13 & $0,435^{* *}$ & 0,161 & 0,672 & 0,577 \\
\hline Wald $_{\text {joint }}: \chi 2(9)$ & \multicolumn{2}{|c|}{$8.865 \mathrm{e}+004[0.000] * *$} & \multicolumn{2}{|c|}{$3.9 \mathrm{e}+004[0.000]^{* *}$} & \multicolumn{2}{|c|}{ 1720.[0.000] } \\
\hline Wald dummy $\chi 2(1)$ & \multicolumn{2}{|c|}{$2.193[0.139$} & \multicolumn{2}{|c|}{$7.2[0.007]^{* *}$} & \multicolumn{2}{|c|}{$1.357[0.244]^{* *}$} \\
\hline Sargan test: $\chi^{2}(201)$ & \multicolumn{2}{|c|}{$218.9[0.184$} & \multicolumn{2}{|l|}{$156.4[0.991]$} & \multicolumn{2}{|c|}{$76.73[1.000]$} \\
\hline $\mathrm{AR}(1)$ test: $\mathrm{N}(0,1)$ & \multicolumn{2}{|c|}{$2.472[0.013] *$} & \multicolumn{2}{|c|}{$1.715[0.086]$} & \multicolumn{2}{|c|}{$1.502[0.133]$} \\
\hline $\mathrm{AR}(2)$ test: $\mathrm{N}(0,1)$ & \multicolumn{2}{|c|}{$-2.137[0.033] *$} & \multicolumn{2}{|c|}{$-1.131[0.258]$} & \multicolumn{2}{|c|}{$-1.748(0.080)$} \\
\hline
\end{tabular}
Investment (gross fixed capital formation $\%$ of GDP)

The dependent variable is investment as percentage of GDP (I/Y). See notations below table 3

Table 6 reports GMM estimates for the total factor productivity (TFP) using equation (4). We find that the effects of real per capita GDP on TFP is significantly negative merely in the Euro Area. In addition, the impact of stock market size is positive and significant at $1 \%$ significance level in most cases. On contrary, the impacts of bank development, volatility and inflation turned out to be significantly negative in all cases at different significance levels. The impact of debt turned to be negligible in all cases. In addition, apart from the Euro Area, the impact of long term interest rate is significantly negative at different significance level. Finally, the impact of liquidity is negative and significant at 5\% significance level merely in the Euro Area. 
Table 6. Analysis of Channels through which bank and financial development may influence economic growth 3Total Factor Productivity

\begin{tabular}{|c|c|c|c|c|c|c|}
\hline & \multicolumn{2}{|c|}{ All Countries } & \multicolumn{2}{|c|}{ Euro Area } & \multicolumn{2}{|c|}{ Non-Euro } \\
\hline & Coefficient & std.error & Coefficient & std.error & Coefficient & std.error \\
\hline $\mathrm{TFP}_{\mathrm{t}-1}$ & $0,844 * * *$ & 0,039 & $0,860 * * *$ & 0,04 & $0,774 * * *$ & 0,027 \\
\hline $\mathrm{RCP}_{\mathrm{t}-1}$ & $-0,001$ & 0,005 & $-0,010^{*}$ & 0,006 & 0,002 & 0,009 \\
\hline Bank $_{t-1}$ & $-0,016 * * *$ & 0,003 & $-0,016^{* *}$ & 0,005 & $-0,021 * * *$ & 0,003 \\
\hline $\mathrm{CAP}_{\mathrm{t}-1}$ & $0,012 * * *$ & 0,003 & $0,014 * * *$ & 0,003 & 0,004 & 0,005 \\
\hline VT t-1 & $-0,004$ & 0,003 & $-0,005^{* *}$ & 0,002 & 0,003 & 0,003 \\
\hline $\mathrm{Vol}_{\mathrm{t}-1}$ & $-0,173 * * *$ & 0,032 & $-0,104 * * *$ & 0,033 & $-0,243 * *$ & 0,115 \\
\hline $\mathrm{Dbt}_{\mathrm{t}-1}$ & 0,003 & 0,005 & 0,003 & 0,003 & 0 & 0,005 \\
\hline $\operatorname{Inf}_{t-1}$ & $-0,001^{*}$ & 0,001 & $-0,002 *$ & 0,001 & $-0,002 * * *$ & 0 \\
\hline $\mathrm{Li}_{\mathrm{t}-1}$ & $-0,003 *$ & 0,001 & $-0,002$ & 0,002 & $-0,007 * * *$ & 0,001 \\
\hline Const. & $0,785^{* * *}$ & 0,201 & $0,791 * * *$ & 0,209 & $1,150 * * *$ & 0,161 \\
\hline Wald $_{\text {joint }}: \chi 2(9)$ & \multicolumn{2}{|c|}{ 3672. $[0.000] * *$} & \multicolumn{2}{|c|}{ 4933.[0.000]** } & \multicolumn{2}{|c|}{$6.17 \mathrm{e}+011[0.000]^{* *}$} \\
\hline Wald $_{\text {dummy }} \chi 2(1)$ & \multicolumn{2}{|c|}{$15.25[0.000] * *$} & \multicolumn{2}{|c|}{$14.38[0.000]^{* *}$} & \multicolumn{2}{|c|}{$51.25[0.000]^{* *}$} \\
\hline Sargan test: $\chi^{2}(222)$ & \multicolumn{2}{|c|}{$214.6[0.627]$} & \multicolumn{2}{|c|}{$160.5[0.999]$} & \multicolumn{2}{|c|}{$79.18[1.000]$} \\
\hline $\mathrm{AR}(1)$ test: $\mathrm{N}(0,1)$ & \multicolumn{2}{|c|}{$3.549[0.000] * *$} & \multicolumn{2}{|c|}{$2.805[0.005]^{* *}$} & \multicolumn{2}{|c|}{$2.132[0.033]^{*}$} \\
\hline $\operatorname{AR}(2)$ test: $\mathrm{N}(0,1)$ & \multicolumn{2}{|c|}{$2.209[0.027] *$} & \multicolumn{2}{|c|}{$1.438[0.150]$} & \multicolumn{2}{|c|}{$-1.400[0.162]$} \\
\hline
\end{tabular}

Finally, we also analyze the effect of financial development on capital intensity, using the following regression:

$$
\text { Intensity }_{i t}=\sum_{k=1}^{p} \alpha_{k} \text { Intensit }_{i, t-k}+y_{i t}, \beta_{\mathbf{1}, \mathbf{1}} S_{i t}+\beta_{\mathbf{2 , 1}} B_{i t}+\beta_{\mathbf{3}, \mathbf{1}} W_{i t}+\beta_{\mathbf{4}, \mathbf{1}} X_{i t}+\lambda_{t}+\eta_{i}
$$

Table 7 reports GMM estimates for capital intensity (net capital stock per employed) using equation 5 . The results suggest that impact of market size on capital intensity is positive and significant in all cases. However, the impacts of banking development, inflation, and volatility are all negative and significant in all cases. In addition, the impacts of liquidity and real per capita income are negative and significant at $5 \%$ significance level merely in the Euro Area. Finally, the impact of debt on capital intensity turned out to be negligible in all cases.

To summarize, we find evidence supporting the channels of saving, investment, TFP, and capital intensity. For all the four channels, the results are generally robust across various models and point to a significant negative relationship of banking development and volatility of stock returns. In addition, for the last three channels investment, TFP and capital intensity the results are generally robust across the different models and refer to a significant positive relationship with market size and a significant negative relationship with inflation rate. However, the results across various models are not convincing for the impact of real per capita GDP, long-term interest rate, liquidity, and debt.

Table 7. Analysis of Channels through which bank and financial development may influence economic growth 4Net Capita stock per employee (Capital intensity)

\begin{tabular}{|c|c|c|c|c|c|c|}
\hline & Coefficient & std.error & Coefficient & std.error & Coefficient & std.error \\
\hline Int $t_{t-1}$ & $0,998 * * *$ & 0,003 & $0,998 * * *$ & 0,008 & $0,998 * * *$ & 0,002 \\
\hline $\mathrm{RCP}_{\mathrm{t}-1}$ & $-0,004$ & 0,007 & 0,007 & 0,011 & $-0,005$ & 0,009 \\
\hline Bank $_{t-1}$ & $0,021 * *$ & 0,006 & $0,021 * *$ & 0,01 & $0,014 * *$ & 0,005 \\
\hline CAP $_{t-1}$ & $-0,011 * *$ & 0,004 & $-0,002$ & 0,003 & $-0,019 * *$ & 0,007 \\
\hline $\mathrm{VT}_{\mathrm{t}-1}$ & 0 & 0,002 & $-0,003$ & 0,002 & $0,013 * * *$ & 0,004 \\
\hline $\mathrm{Vol}_{\mathrm{t}-1}$ & $0,161 * *$ & 0,051 & 0,096 & 0,068 & 0,123 & 0,105 \\
\hline $\mathrm{Dbt}_{\mathrm{t}-1}$ & $-0,014 * *$ & 0,004 & $0,043 * *$ & 0,015 & $-0,007$ & 0,008 \\
\hline $\operatorname{Inf}_{t-1}$ & 0 & 0 & 0,002 & 0,001 & 0 & 0 \\
\hline $\mathrm{Li}_{\mathrm{t}-1}$ & 0 & 0,001 & 0,001 & 0,001 & $0,002 * *$ & 0,001 \\
\hline Const. & 0,063 & 0,064 & $-0,143$ & 0,108 & 0,037 & 0,118 \\
\hline Wald joint $\chi 2(9)$ & \multicolumn{2}{|c|}{$1.264 \mathrm{e}[0.000]^{* *}$} & \multicolumn{2}{|c|}{$1.278 \mathrm{e}[0.000]^{* *}$} & \multicolumn{2}{|c|}{$9.239 \mathrm{e}[0.000]^{* *}$} \\
\hline Wald $_{\text {dummy }} \chi 2(1)$ & \multicolumn{2}{|c|}{$\begin{array}{lll}0.980 & 0.322]\end{array}$} & \multicolumn{2}{|c|}{1.743 [0.187] } & \multicolumn{2}{|c|}{$0.09889[0.753]$} \\
\hline Sargan test: $\chi^{2}(222)$ & \multicolumn{2}{|c|}{$125.4[1.000]$} & \multicolumn{2}{|c|}{$144.9[1.000]$} & \multicolumn{2}{|c|}{$73.38[1.000]^{*}$} \\
\hline $\mathrm{AR}(1)$ test: $\mathrm{N}(0,1)$ & \multicolumn{2}{|c|}{$2.806[0.005] * *$} & \multicolumn{2}{|c|}{$2.581[0.010]^{* *}$} & \multicolumn{2}{|c|}{$2.137[0.033]$} \\
\hline $\mathrm{AR}(2)$ test: $\mathrm{N}(0,1)$ & \multicolumn{2}{|c|}{$2.206[0.027] *$} & \multicolumn{2}{|c|}{$2.266[0.023]^{*}$} & \multicolumn{2}{|c|}{$-0.1160[0.908]$} \\
\hline
\end{tabular}


The dependent variable is net capital stock per employee. See notations below table 3

\subsection{Non-linear Effects and Threshold of Public Debt}

The above results across various models are neither decisive nor robust for the impact of public debt on real GDP per capita, investment, saving, TFP and intensity. A number of studies find support for non-linear impact of debt on growth of real GDP, with deleterious effects only after a certain debt-to-GDP ratio threshold (see for instance Prasad et al. 2003, Reinhart and Rogoff 2010; Kumar and Woo 2010; and Checherita et al. 2010).

The presence of the non-linear effects of public debt is analyzed in two ways. First, we permit the coefficients $\beta \mathrm{s}$ in equation (1) to differ between high and low debt values. Noteworthy differences in coefficients across these two groups can be understood as evidence of non-linear effects of public debt on real GDP per capita. Second, we use the squared debt as explanatory variable in the regression where a significant value would be considered as evidence of nonlinearity. Thus, our econometric investigation with panel data is described in the following regression specification:

$$
\begin{gathered}
\Delta y_{i t}=\sum_{k=1}^{p} \alpha_{k} y_{i, t-k} \quad \beta_{\mathbf{1 , 1}} S_{i t}+\beta_{\mathbf{2 , \mathbf { 1 }}} B_{i t}+\beta_{\mathbf{3}, \mathbf{1}} W_{i t}+\beta_{\mathbf{4 , \mathbf { 1 }}} X_{i t}+\lambda_{t}+\eta_{i}+v_{i t} \quad \text { if } X_{i} \leq \lambda \\
\Delta y_{i t}=\sum_{k=1}^{p} \alpha_{k} y_{i, t-k}+\beta_{\mathbf{1 , 2}} S_{i t}+\beta_{\mathbf{2 , 2}} B_{i t}+\beta_{\mathbf{3}, \mathbf{2}} W_{i t}-\beta_{\mathbf{4 , 2}} X_{i t}+\lambda_{t}+\eta_{i}+v_{i t} \quad \text { if } X_{i}>\lambda
\end{gathered}
$$

Where the dependent variable, $\Delta \mathrm{y}_{\mathrm{it}}$, is the growth of real per-capita GDP. As before, we use lag one of the explanatory variables to avoid the endogeneity problem posed by this variable. In equations $6 \& 7$ the coefficients $\beta$ s are allowed to switch between groups depending on the value of an observable threshold value $(\lambda)$. We calculate for the 16 countries the average public debt-to- GDP ratio and use this variable as a threshold value $(\lambda)$, which turned out to be $65 \%$. Although such procedure does not yield an exact and consistent estimate of threshold values, examination of estimates of $\beta$ across different values of $\lambda$ produces a primary evidence of conceivable threshold effects. The growth enhancing or corrupting effects of financial development and debt will vary with the threshold condition. Moreover, the endogeneity problem is also diminished in our specification by the fact that the explanatory variables all have at least one lag compared to the dependent variable.

Table 8 reports GMM estimates of the dynamic panel model based on level of debt as percentage of GDP were estimated using the econometric procedure presented above. Specifically, we estimated the coefficients $\beta$ s in equations 5 and 6 for three groups: (i) high debt nations with an average debt of GDP ratio above 65\%; (ii) moderate debt nations with a debt of GDP ratio between $45 \%$ and $65 \%$; and (iii) low debt nations with an average debt of GDP ratio below $45 \%$. The results show impact of stock market size always stimulates growth with significance varying across groups. Generally, volatility (VOL), bank development (Bank), and inflation (inf.) have corrupting effects on growth with significance varying across groups. The effect of openness, however, is positive and significant in all cases. Thus, in contrary to Arestis et al. (2001), our results show that the impact of stock markets on economic growth appears to be substantially larger compared to bank finance.

The debt squared variable (debtSQR) also turns out to be significant particularly in countries with a debt ratio lower than $45 \%$, which provides indication of non-linear effect of public debt on the growth rate of real GDP per-capita and reveals a concave link between debt and economic growth. The concave link between debt and economic growth is also supported by the sign and significance of public debt across the three groups. The coefficient of public debt, dbt, is negative and significant at $1 \%$ and $5 \%$ significance level for countries with high and moderate debt-to-GDP ratio (column 2 and 4), respectively. The coefficient, however, turns positive for countries with debt- to- GDP lower than $45 \%$ (column 6). Thus, the estimations establish a threshold between 45 -65 percent public debt-to-GDP ratio. If debt is above this threshold, any additional increase of public debt costs about 0.003 percentage points of annual real per-capita growth. (Note 2) Besides including the initial debt/GDP (1989) to control for omitted variables, bias and reverse causality, estimations are repeated adding other control variables such as secondary school enrollment, number of domestic companies, R \& D as percentage of GDP, and population growth. The results remain in principle the same with almost the same threshold values and small changes of the coefficients among the three groups.

\section{Conclusions}

This paper studied the empirical relationship between several measures of stock market development, banking development, public debt, and economic growth using a sample of 11 Euro countries and 5 non-Euro countries over the period 1989-2011. We found that, although, loans made by banks to private enterprises grew remarkably 
faster in the Euro Area than in the US, Sweden and Norway in the post Euro era, slower growth of total factor productivity, increase of stock market volatility, and negative growth of liquidity and market capitalization in the Euro Area since 1999 are largely responsible for the weaker growth of real GDP per-capita.

Using GMM procedure across the various control variables, we found that the impact of stock market size is always positive whether we take the level of real per capita income or its growth. However, the impacts of banking sector, volatility, liquidity, and public debt are generally negative. Inflation rates and long term interest rates as control variables for overall macroeconomic instability are generally negative. We find indication for the channels of saving, investment, TFP, and capital intensity. For all the four channels, the results are robust across the various models and refer to a significant negative relationship of banking development and volatility of stock returns. In addition, for the last three channels -investment, TFP and capital intensity the results are generally robust across the different models and refer to a significant positive relationship to market size and a significant negative relationship of inflation rate. However, the results across various models is not convincing for the real per capita GDP, long term interest rate, liquidity and debt.

We also found evidence for a non-linear effect of public debt on per-capita GDP growth rate across 11 countries. It exposes a concave link between the public debt and economic growth where turning point is likely to be between $45-65 \%$. This implies that a higher public debt-to-GDP ratio is allied, on average, with lower real growth rate at debt levels above the range of $45-65 \%$. The paths through which debt is expected to affect real per capita GDP growth appear to be saving, investment, total factor productivity, capital intensity and long term interest rate.

Table 8. GMM- Threshold regression based on estimated threshold debt level, dependent variable growth of real GDP per capita; one-step results

\begin{tabular}{|c|c|c|c|c|c|c|}
\hline & $\begin{array}{l}\text { Debt }>65 \% \\
\text { of GDP }\end{array}$ & $\begin{array}{l}\text { Std. } \\
\text { error }\end{array}$ & $\begin{array}{l}65 \%>\text { Debt }< \\
45 \%\end{array}$ & Std.error & Debt $<45 \%$ of GDP & Std.error \\
\hline Initial RCP & $-0,0024 * * *$ & 0 & $-0,0046$ & 0 & 0,0002 & 0 \\
\hline Bank & 0,0088 & 0,0001 & $-0,0002 *$ & 0,0001 & $-0,0004 * *$ & 0,0001 \\
\hline Bank(-1) & 0,0006 & 0,0001 & 0 & 0,0001 & 0 & 0,0001 \\
\hline CAP & 0,0001 & 0,0001 & $0,0001 * *$ & 0 & 0,0001 & 0,0001 \\
\hline CAP(-1) & $0,0018 * * *$ & 0,0001 & $-0,0004$ & 0 & $0,0039 * *$ & 0,0001 \\
\hline VT & 0,0049 & 0 & 0,0045 & 0 & 0,0018 & 0 \\
\hline VT(-1) & $-0,0001 * * *$ & 0 & $-0,0033$ & 0 & $-0,0001$ & 0,0001 \\
\hline Vol & $-0,1888^{* *}$ & 0,1595 & 0,0311 & 0,0586 & $-0,0385$ & 0,1061 \\
\hline Vol(-1) & $-0,0441$ & 0,1114 & $-0,1022 * *$ & 0,0412 & $-0,0958$ & 0,0338 \\
\hline Dbt & $-0,0043 * * *$ & 0,0012 & $-0,0032 * *$ & 0,0012 & $-0,0044$ & 0,003 \\
\hline Dbt(-1) & 0,0048 & 0,0015 & 0,0032 & 0,0013 & $0,0037 * *$ & 0,0018 \\
\hline DebtSQR & 0,001 & 0 & 0,0013 & 0 & $0,0031 * *$ & 0 \\
\hline DebtSQR(-1) & $-0,0014$ & 0 & $-0,0013$ & 0 & $-0,0027^{*}$ & 0 \\
\hline Openness & $0,0010^{* * *}$ & 0,0003 & $0,0020 * * *$ & 0,0002 & $0,0022 *$ & 0,0003 \\
\hline Openness (-1) & $-0,001$ & 0,0003 & $-0,0019$ & 0,0002 & $-0,0016$ & 0,0003 \\
\hline Inf & $-0,0016$ & 0,0019 & 0,0002 & 0,0006 & $-0,0003^{* *}$ & 0,001 \\
\hline $\operatorname{Inf}(-1)$ & $0,0024 *$ & 0,0012 & $-0,0006$ & 0,0004 & $-0,0008^{* *}$ & 0,0003 \\
\hline $\mathbf{L i}$ & 0,0037 & 0,0022 & $0,0048 * *$ & 0,0009 & 0,0011 & 0,0004 \\
\hline Li(-1) & 0,001 & 0,002 & $-0,0039$ & 0,0012 & $-0,0012$ & 0,0009 \\
\hline Constant & 0,0097 & 0,0199 & $0,0412 * *$ & 0,0117 & $-0,0023$ & 0,0594 \\
\hline Wald Joint: $\chi 2(199$ & \multicolumn{2}{|c|}{$105.2(0.000)^{* *}$} & \multicolumn{2}{|l|}{ 1311. $[0.000] * *$} & \multicolumn{2}{|l|}{$11.95[0.888$} \\
\hline Wald Dummy $\chi 2(1)$ & \multicolumn{2}{|c|}{$0.2389[0.625$} & \multicolumn{2}{|l|}{$12.40[0.000] * *$} & \multicolumn{2}{|l|}{$0.001559[0.969]$} \\
\hline Sargan test: $\chi^{2}(212)$ & \multicolumn{2}{|c|}{$86.29[1.000]$} & \multicolumn{2}{|l|}{$132.9[1.000]$} & \multicolumn{2}{|l|}{$39.40[1.000]$} \\
\hline $\mathrm{AR}(1)$ test: $\mathrm{N}(0,1)$ & \multicolumn{2}{|c|}{$0.4337[0.665]$} & \multicolumn{2}{|l|}{$2.004[0.045] *$} & \multicolumn{2}{|l|}{$0.9175[0.359]$} \\
\hline
\end{tabular}

The dependent variable is the growth of real per-capita GDP, Initial RCP= initial real GDP per capita, Bank = loans made by banks to private enterprises as percentage of GDP, CAP = market capitalization as percentage of GDP, $\mathrm{VOL}=$ volatility of stock market returns, $\mathrm{VT}=$ value of stock trading as percentage of GDP, Dbt $=$ public debt as percentage of GDP, DebtSQR =squared Public debt, Openness = import + export as a percentage of GDP, 
inf $=$ inflation rate, $\mathrm{Li}=$ long term interest rate , and $(-1)=$ one lag. There are 6 countries in the first group (Austria, Belgium, Greece, Ireland, Italy, and US), 5 in the second group (France, Germany, Portugal, Spain, and Sweden), and 5 in the third group (Finland, Netherlands, United Kingdom, Norway and Denmark).

\section{References}

Atje, R., \& Jovanovic, B. (1993). Stock markets development. Eur. Econ. Rev., 37, 632-640. http://dx.doi.org/10.1016/0014-2921(93)90053-D

Arestis, P., Demetriades, P., \& Luintel, K. (2001). Financial development and economic growth: the role of stock markets. J. Money Credit Bank, 33, 16-41. http://dx.doi.org/10.2307/2673870

Baele, L., Ferrando, A., Hördahl, P., Krylova, E., \& Monnet., C. (2004). Measuring Financial Integration in the Euro Area. ECB Occasional Paper No. 14.

Ben Naceur, S., \& Ghazouani, S. (2007). Stock markets, banks, and economic growth: Empirical evidence from the MENA region. Research in International Business and Finance, 21, 297-315. http://dx.doi.org/10.1016/j.ribaf.2006.05.002

Caner, M., Grennes, T., \& Geib, F. (2010). Finding the Tipping Point-When Sovereign Debt Turns Bad. Policy Research Working Paper 5391.

Checherita, C., \& Rother, P. (2010). The impact of high and growing government debt on economic growth: an empirical investigation for the euro area. Working Paper Series, 1237, European Central Bank.

Denison, E. F. (1985). Trends in American Economic Growth, 1929-1982. Washington, D.C.:Brookings Institution.

Doornik, J. A., \& Hendry, D. F. (2007). Econometric modeling PCGive12, III. Timberlake Consultants LTD, London.

DeLong, J., B., Shleifer, A., Summers, L., \& Waldmann, R. (1989). The Size and Incidence of Losses from Noise Trading. Journal of Finance, 44(3), 681-696.

Hali J. E., Levine, R., Ricci, L., \& Sløk, T. (2002). International Financial Integration and Economic Growth. Journal of International Money and Finance, 749-776. http://dx.doi.org/10.3386/w9164

European Central Bank (ECB). Financial Integration in Europe. Downloadable at http://www.ecb.int/pub/pdf/other/financialintegrationineurope200804en.pdf (2008).

European Central Bank (ECB). Financial Integration in Europe. Downloadable at http://www.ecb.int/pub/pdf/other/financialintegrationineurope200904en.pdf (2008).

Feldman, R. (1998). Impact of EMU on selected non-European-Union countries. International Monetary Fund, 174.

Giannone, D., \& Reichlin, L. (2006). Does information help recovering structural shocks from past observations? Journal of the European Economic Association, P\&P, 4.

Gianetti, M. (2002). The effects of integration on regional disparities: Convergence, divergence or both? European Economic Review, 46, 539-567. http://dx.doi.org/10.1016/S0014-2921(01)00166-0

Guiso, L., T. Jappelli, M. Padula, \& M. Pagano. (2004). Financial Market Integration and Economic Growth in the EU. Economic Policy, 523-577. http://dx.doi.org/10.1111/j.1468-0327.2004.00131.x

Goldsmith, R. (1969). Financial Structure and development. New Haven and London: Yale University Press.

Hall, R. E., \& Jones, C. I. (1999). Why do some countries produce so much more output per worker than others? Quarterly Journal of Economics, 114, 173-177.

Hardouvelis, G. A., Malliaropulos, D., \& Priestley, R. (2006). EMU and European Stock Market Integration. Journal of Business, 79(1), 365-392.

Hansson, P., \& Jonung, L. (1997). Finance and Economic Growth: The Case of Sweden 1834-1991. Research in Economics.

Hall, R., \& Jorgenson, D. (1967). Tax Policy and Investment Behavior. American Economic Review, 5.

Hiebert P., A. Lamo, D. R. de Avila, \& J. P. Vidal. (2002). Fiscal Policies and Economic Growth in Europe: An Empirical Analysis. Paper presented at the 2002, Banca d'Italia Public Finance Workshop on the Impact of Fiscal Policy.

Hondroyiannis, G., Lolos, S., \& Papapetrou, E. (2005). Financial markets and economic growth in Greece, 1986-1999. Int. Fin. Markets, Inst. and Money, 15, 173-188. http://dx.doi.org/10.1016/j.intfin.2004.03.006 
Hornstein, A., \& P. Krusell (1996). Can Technology Improvements Cause Productivity Slowdowns. NBER Macroeconomics Annual 11. (MIT Press: Cambridge MA), 209-259.

Jorgenson, D. (1963). Capital Theory and Investment Behavior. American Economic Review, 247-259.

King, R. G., \& Levine, R. (1993). Finance and Growth: Schumpeter Might Be Right. Quarterly Journal of Economics, 108(3), 717-37. http://dx.doi.org/10.2307/2118406

Kumar, S., \& Woo, J. (2010). Public Debt and Growth. IMF Working Paper, WP/10/174, International Monetary Fund.

Lahiani, A., \& Scailleto, O. (2009). Testing for threshold effect in ARFIMA models: Application to US unemployment rate data. International Journal of Forecasting, 25(2), 418-428.

Levine, R. (1991). Stock Markets, Growth, and Tax Policy. Journal of International Economics, 30(3-4), 359-369. http://dx.doi.org/10.1016/0022-1996(91)90028-5

Levine, R., \& Zervos, S. (1998). Stock markets, banks, and economic growth. The American Economic Review, $88(3), 537$.

Levine, R. (2000). Bank-Based or Market-Based Financial Systems: Which is Better? Mimeo, University of Minnesota, January.

Levine, R., Loayza, N., \& Beck, T. (2000). Financial Intermediation and Growth: Causality and Causes. Journal of Monetary Economics, 46(1), 31-77. http://dx.doi.org/10.1016/S0304-3932(00)00017-9

London economics. (2002). Quantification of the macro-economic impact of integration of EU financial markets. Executive summary of the final report to the European commission - Directorate-General for the Internal Market.

McKinnon, R. (1973). Money and Capital in Economic Development. Washington, DC: Brookings Institution.

Masson, P. R., T. Bayoumi, \& H. Samiei. (1998). International Evidence on the Determinants of Private Saving. The World Bank Economic Review, 12(3), 483-501. http://dx.doi.org/10.1093/wber/12.3.483

Maudos, J., \& Guevara, F. (2010). Financial Crisis, Financial Integration and Economic Growth: The European Case. Working Papers 20108, Fundacion BBVA / BBVA Foundation.

Pagano, M., \& von Thadden, E. (2004). The European Bond Markets under EMU. CSEF Working Papers 126.

Prescott, C. (1997). Needed: A Theory of Total Factor Productivity. Federal Reserve Bank of Minneapolis Research Department, Staff Report 242.

Rajan, R., \& Zingales, L. (1998). Financial dependence and growth. American Economic Review, 88, 559-587.

Reinhart, M., \& Rogoff, K. (2010). Growth in a Time of Debt. American Economic Review: Papers \& Proceedings, 100(2), 1-9. http://dx.doi.org/10.1257/aer.100.2.573

Rousseau, P., \& Wachtel, P. (1998). Financial Intermediation and Economic Performance: Historical Evidence from Five Industrialized Countries. Journal of Money Credit and Banking, 657. http://dx.doi.org/10.2307/2601123

Schclarek, A. (2004). Debt and economic growth in developing industrial countries mimeo.

Shaw, E. (1973). Financial deepening in economic development. New York: Oxford University Press.

Solow, R. (1957). Technical Change and the Aggregate Production Function. The Review of Economics and Statistics, 39, 312-320. http://dx.doi.org/10.2307/1926047

Pattillo, C., Poirson, H., \& Ricci, L. (2002), External Debt and Growth, IMF Working Paper02/69.

Prasad, E., Rajan, R., \& Subramanian, A. (2007). Foreign Capital Economic Growth. Brookings, paper on Economic Activity, September. http://dx.doi.org/10.1353/eca.2007.0016

Van Nieuwerburg, S., Buelens, F., \& Cuyvers, L. (2006). Stock Market Development and Economic Growth in Belgium. Explorations in Economic History, 43(1), 3-38.

\section{Notes}

Note1. For a similar expression, see for example Levine \& Zervos (1998), Ben Naceur et al. (2007)

Note 2. One can also use polynomial function, Delta-Method or Bootstrap techniques to estimate the debt turning points. We will tackle this issue through panel data analysis in a future projects. 